\title{
EDUKASI SADAR BENCANA MELALUI SOSIALISASI KEBENCANAAN SEBAGAI UPAYA PENINGKATAN PENGETAHUAN SISWA TERHADAP MITIGASI BENCANA
}

\author{
Muhammad Rizal Pahleviannur \\ Pendidikan Geografi, Universitas Muhammadiyah Surakarta \\ e-mail: pahlevi.geoedu@gmail.com
}

\begin{abstract}
Indonesia is a country that has a high level of vulnerability to natural disasters. Based on the disaster index of risk, Central Java Province is one of the provinces that experienced the most disasters in Indonesia. Community preparedness efforts towards disasters are still considered weak, as evidenced by the large number of fatalities, property losses, and deaths. Children are classified as vulnerable to disaster management efforts and therefore require special efforts to increase knowledge about disaster mitigation. This study aims to increase students knowledge of disaster mitigation through disaster preparedness socialization activities to realize disaster resilient schools. This research is one form of community service through socialization activities with a qualitative approach. The result of the study show that the level of students knowledge of disaster mitigation still needs for improving more. Low knowledge can increase the number of casualties resulting from disasters. The solution offered by researchers is conducting disaster awareness education activities through disaster socialization. It is expected that follow up actions such as maintenance and supervision as controls with the aim of such activities have optimal result to increase students knowledge of disaster mitigation and the realization of disaster resilient schools.
\end{abstract}

Keywords: Disaster mitigation, student knowledge, disaster resilient.

\section{PENDAHULUAN}

Letak geografis Indonesia yang terletak pada pertemuan tiga lempeng aktif, yaitu Indo-Australia, Eurasia, dan Pasifik mengakibatkan kondisi negara Indonesia memiliki tingkat kerawanan tinggi terhadap bencana geologis dan hidroklimatologis. Berdasarkan data Badan Nasional Penanggulangan Bencana (BNPB) Tahun 2018, kejadian bencana yang terjadi di Indonesia mengalami 3.397 kejadian, dengan 3.874 korban jiwa meninggal dan hilang. Dalam kurun waktu sepuluh tahun terakhir dari Tahun 2009-2018, dampak terjadinya bencana sangat bervariasi, mulai dari kerusakan, kerugian, hingga menimbulkan korban jiwa. 
Kondisi tersebut memperlihatkan masih lemahnya kesiapsiagaan terhadap bencana yang terjadi di Indonesia.

Menurut Undang-undang Nomor 24 Tahun 2007 tentang Penanggulangan Bencana, bencana adalah peristiwa atau rangkaian peristiwa yang mengancam dan mengganggu kehidupan dan penghidupan masyarakat yang disebabkan, baik oleh faktor alam dan/atau faktor non alam maupun faktor manusia, sehingga mengakibatkan timbulnya korban jiwa manusia, kerusakan lingkungan, kerugian harta benda, dan dampak psikologis. Provinsi Jawa Tengah mengalami peristiwa bencana sebanyak 585 kejadian dengan indeks risiko terjadi bencana terbesar di Indonesia. Hal tersebut menunjukkan bahwa wilayah-wilayah yang berada di Provinsi Jawa Tengah memiliki potensi yang besar terhadap terjadinya bencana.

Kabupaten Boyolali sebagai salah satu kabupaten yang terletak di Provinsi Jawa Tengah memiliki potensi terjadi bencana puting beliung, tanah longsor, letusan gunung api, banjir, dan kekeringan (BNPB, 2018). Menurut Rinaldi (2009), kesiapsiagaan bencana masyarakat Indonesia masih lemah, hal tersebut dibuktikan dengan banyaknya jumlah korban jiwa dan korban harta benda dari setiap kejadian bencana.

Bencana alam merupakan fenomena alam yang tidak seorang manusiapun mampu memperkirakan kapan terjadinya, walaupun manusia dengan segala pengetahuannya berusaha untuk membaca fenomena alam tersebut (Emosda, Lela, \& Fadzlul, 2014). Upaya pengurangan risiko bencana dilakukan dengan pertimbangan beberapa aspek, seperti aspek keberlanjutan dan partisipasi dari semua elemen masyarakat yang ada. Pada kelompok usia anak, dampak bencana dipandang lebih mengkhawatirkan, sehingga dalam Undang-undang Nomor 24 Tahun 2007 tentang Penanggulangan Bencana, anak-anak dikelompokkan dalam kategori rentan. Hal tersebut memiliki arti bahwa anak-anak memerlukan upaya khusus mengenai pemahaman mitigasi bencana.

Anak-anak merupakan salah satu kelompok yang paling rentan berisiko terkena dampak bencana (PP No 21, 2008). Kerentanan anak-anak terhadap bencana dipicu oleh faktor keterbatasan pemahaman tentang risiko-risiko di sekeliling mereka, yang berakibat tidak adanya kesiapsiagaan dalam menghadapi bencana. Berdasarkan data kejadian bencana di beberapa daerah, banyak korban akibat bencana pada anak usia sekolah, baik di jam sekolah maupun di luar jam sekolah. Hal ini menunjukkan bahwa pentingnya pengetahuan tentang bencana dan pengurangan risiko bencana sejak dini untuk memberikan pemahaman dan pengarahan langkah-langkah yang harus dilakukan saat terjadi suatu ancaman yang ada di sekitarnya untuk mengurangi risiko bencana (Sunarto, 2012).

Kerugian pada elemen sekolah, seperti guru dan siswa, proses pembelajaran, properti, dan penyediaan akibat bencana mengakibatkan jutaan masa depan generasi muda terancam (Lesmana dan Purobrini, 2015). Selaras dengan perjanjian yang ditetapkan oleh Hyogo Framework for Action Tahun 2005, bahwa prioritas pengurangan risiko bencana perlu diimplementasikan ke dalam sektor pendidikan. Jika hal tersebut terus terjadi, sulit untuk mewujudkan generasi dan sekolah yang tangguh bencana jika anak-anak tidak memiliki kesiapsiagaan yang baik mengenai bencana.

Anak-anak memiliki kerentanan bencana yang lebih rendah dibandingkan dengan orang dewasa. Pendidikan kebencanaan di sekolah dasar dan menengah 
mampu membantu anak-anak memainkan peranan penting dalam penyelamatan hidup dan perlindungan anggota masyarakat (Honesti \& Djali, 2012). Sekolah memiliki peranan yang sangat strategis dalam upaya penanggulangan bencana, karena sekolah mampu meningkatkan pengetahuan dan keterampilan siswa dalam menghadapi bencana. Sekolah sebagai satuan pendidikan memiliki tanggung jawab untuk menyelenggarakan pendidikan, khususnya mengenai kesiapsiagaan bencana. Pendidikan kebencanaan harus dimulai sejak usia dini. Hal ini didasarkan pada fakta bahwa setiap tahun diperkirakan sekitar 66 juta anak di seluruh dunia terkena dampak bencana (Herdwiyanti \& Sudaryono, 2013).

Menurut A Dariyo (2013), siswa Sekolah Dasar (SD) berada pada masa anak tengah (middle childhood). Siswa pada masa anak tengah memiliki kondisi rentan secara psikologis dan memiliki kemungkinan untuk mengalami stres akibat kejadian bencana (Peek, 2008). Pendidikan kebencanaan harus dimulai sejak dini. Hal ini didasarkan pada fakta setiap tahun diperkirakan sekitar 66 juta anak di seluruh dunia terkena dampak bencana (F Herdwiyanti \& Sudaryono, 2013). Untuk mengurangi risiko dari terjadinya bencana, peningkatan pemahaman melalui pengetahuan memiliki urgensi yang penting. Salah satu cara meningkatkan kesadaran adalah dengan mengubah pengetahuan seseorang terhadap suatu hal (Duval, dkk, 2000). Jika pengetahuan anak-anak terhadap bencana tergolong baik, maka dapat mewujudkan generasi yang tangguh bencana dan memiliki kesiapsiagaan yang baik terhadap bencana.

Peningkatan pengetahuan untuk sadar terhadap kesiapsiagaan bencana dapat dilakukan dengan sosialisasi dengan tujuan untuk mengedukasi. Hal tersebut selaras dengan kegiatan yang dilakukan oleh BNPB, bahwa sosialisasi sadar bencana sangat penting dilakukan untuk mengurangi dampak saat terjadi bencana. Target sasaran sosialisasi peneliti merupakan salah satu sekolah yang terdapat di wilayah rawan bencana yaitu SD Negeri 1 Jrakah, terletak di Kelurahan Jrakah, Kecamatan Selo, Kabupaten Boyolali, Provinsi Jawa Tengah. Edukasi kebencanaan memiliki manfaat penting yaitu tidak menutup kemungkinan bahwa dampak dari suatu bencana akan hilang dan setidaknya dapat mengurangi risiko terjadinya bencana.

Strategi komunikasi yang dilakukan oleh BNPB adalah melakukan edukasi bencana, seperti pemberian materi berupa pengertian bencana, dampak yang ditimbulkan dari bencana, hingga upaya untuk mitigasi bencana tersebut. Anakanak memiliki kerentanan bencana yang lebih tinggi dibandingkan dengan orang dewasa, hal tersebut dikarenakan anak-anak masih belum mampu untuk mengontrol dan mempersiapkan diri saat situasi bencana (Sulistyaningsih, 2011; F Herdwiyanti \& Sudaryono, 2013).

Dengan demikian, anak-anak memerlukan peningkatan pengetahuan dan pemahaman mengenai kesiapsiagaan bencana, sehingga cara komunikasi yang tepat yaitu melalui sosialisasi sadar bencana. Berdasarkan uraian yang telah dijelaskan di atas, peneliti merumuskan penelitian yang berjudul "Edukasi Sadar Bencana Melalui Sosialsiasi Kebencanaan Sebagai Upaya Peningkatan Pengetahuan Siswa Terhadap Mitigasi Bencana" dan penelitian ini memiliki tujuan untuk meningkatkan pengetahuan siswa-siswi terhadap mitigasi bencana melalui kegiatan sosialisasi siaga bencana demi mewujudkan sekolah tangguh bencana. 


\section{METODE PENELITIAN}

Penelitian ini merupakan salah satu bentuk pengabdian masyarakat melalui kegiatan sosialisasi dengan pendekatan kualitatif. Menurut Sugiyono (2007:14) metode kualitatif digunakan untuk mendapatkan data yang mendalam yaitu data yang mengandung makna. Khalayak dan sasaran dalam kegiatan sosialisasi ini adalah siswa-siswi SD N 1 Jrakah yang terletak di Kelurahan Jrakah, Kecamatan Selo, Kabupaten Boyolali.

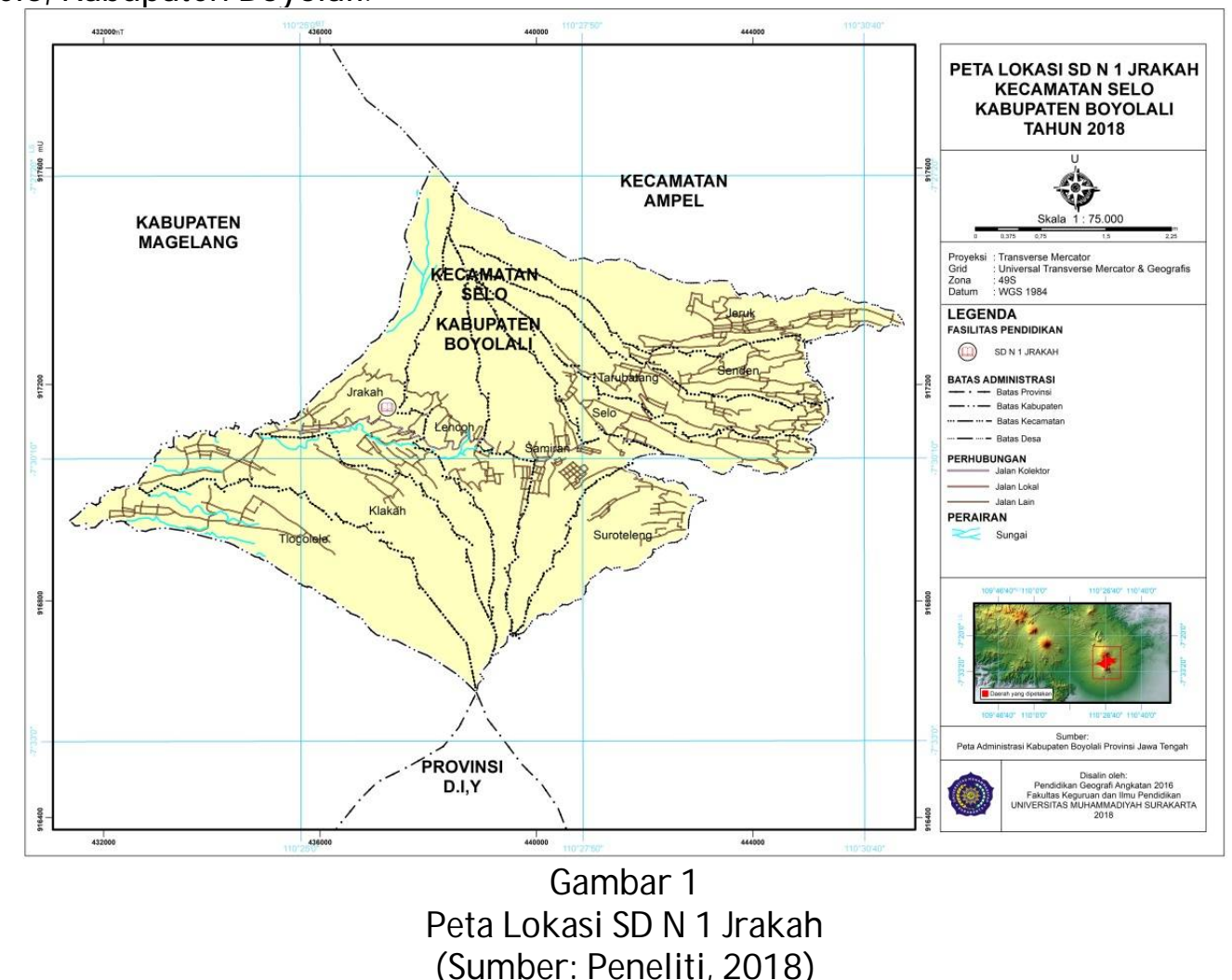

Model kegiatan yang dilakukan berupa sosialisasi mengenai materi kebencanaan yang berpotensi di wilayah penelitian. Adapun langkah yang dilakukan untuk mencapai tujuan pada kegiatan ini adalah:

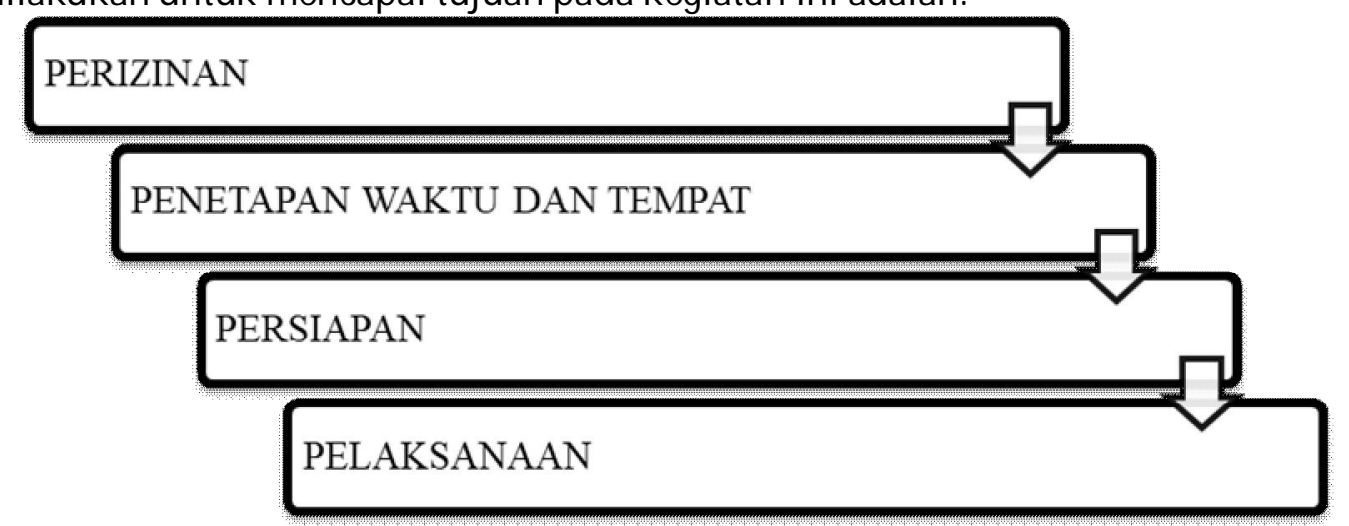

Gambar 2

Diagram Alur Penelitian

(Sumber: Peneliti, 2019) 
a. Proses pengurusan perizinan dilakukan bersama dengan pihak sekolah untuk melakukan sosialisasi,

b. Berkoordinasi dengan sekolah terkait perihal waktu dan tempat,

c. Menyiapkan topik atau materi yang akan disampaikan dalam kegiatan sosialisasi, dan

d. Pelaksanaan sosialisasi di SD N1 Jrakah.

\section{HASIL PENELITIAN DAN PEMBAHASAN}

\section{A. Analisis Situasi}

Kecamatan Selo merupakan salah satu kecamatan yang berada di Kabupaten Boyolali, tepatnya terletak di antara dua gunung, yaitu Gunung Merapi dan Gunung Merbabu. Gunung Merapi merupakan salah satu gunung yang masih aktif mengeluarkan lahar panas maupun lahar dingin. Sesuai dengan informasi dari Badan Pengawas Gunung, $20 \mathrm{Km}$ merupakan zona aman dari ketinggian dan bencana letusan gunung berapi merupakan letusan yang terhitung lama hingga banyak memakan korban jiwa.

Bencana yang dapat terjadi di Kecamatan Selo selain letusan gunung berapi juga berpotensi terhadap bencana tanah longsor. Kecamatan Selo merupakan wilayah yang memiliki lereng curam, berada pada kemiringan antara $12^{\circ}-40^{\circ}$ (26,67\%-88,89\%) dan curah hujan tergolong cukup tinggi yaitu 3.842,5 Mm dengan jumlah hari hujan yaitu $219 \mathrm{Hh}$, sehingga memiliki potensi terjadi longsor (BPS, 2018).

Faktor utama yang mempengaruhi tingkat bahaya longsor di SD N 1 Jrakah adalah tingkat kemiringan lereng, tekstur tanah, dan ketebalan solum tanah. Kemiringan lereng yang semakin besar berpengaruh terhadap tingkat bahaya longsor yang semakin besar. Kemiringan lereng berperan sebagai pemicu terjadinya longsor. Selain itu, kemiringan lereng juga memungkinkan tenaga gravitasi berperan lebih optimal dalam menyebabkan terjadinya longsor.

\section{B. Permasalahan}

Tingkat pengetahuan siswa di SD N 1 Jrakah mengenai kesiapsiagaan bencana menjadi perhatian yang paling utama. Upaya mitigasi atau pencegahan untuk meningkatkan pengetahuan siswa terhadap kesiapsiagaan bencana perlu diadakan, salah satu kegiatan yang dapat dilakukan melalui edukasi sadar bencana dalam bentuk sosialisasi kebencanaan. Pengetahuan siswa tentang bencana perlu ditingkatkan dengan memberikan edukasi mengenai mitigasi bencana yang paling praktis dan sederhana. Rendahnya pengetahuan bencana dapat meningkatkan terjadinya korban akibat dari bencana.

\section{Solusi}

Berdasarkan uraian permasalahan di atas, peneliti melakukan edukasi sadar bencana melalui kegiatan sosialisasi dengan tujuan untuk meningkatkan pengetahuan kesiapsiagaan siswa di SD N 1 Jrakah. 


\section{Pelaksanaan dan Keberlanjutan}

1. Pelaksanaan

Sosialisasi yang dilaksanakan di SD N 1 Jrakah dilaksanakan pada hari Jumat, 14 Desember 2018.

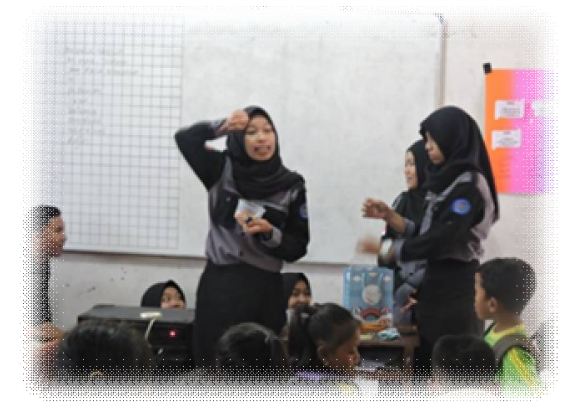

Gambar 3

Kegiatan Sosialisasi

(Sumber: Peneliti, 2018)

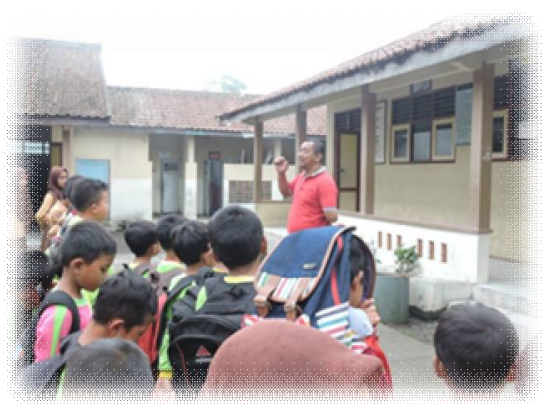

Gambar 5

Arahan dari Kepala Sekolah

(Sumber: Peneliti, 2018)

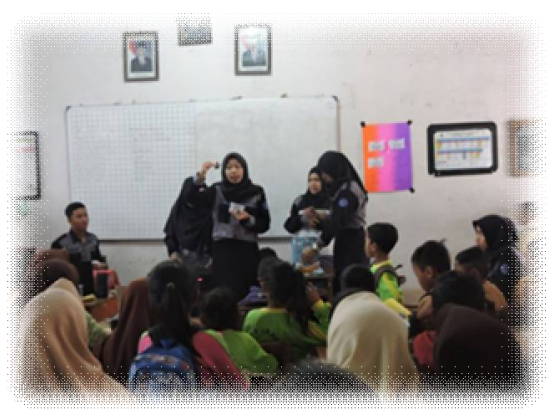

Gambar 4

Kegiatan Sosialisasi

(Sumber: Peneliti, 2018)

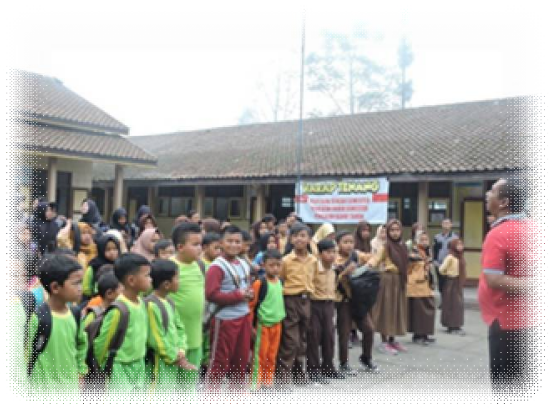

Gambar 6

Arahan dari Kepala Sekolah

(Sumber: Peneliti, 2018)

\section{Keberlanjutan}

Dalam hal keberlanjutan, perlu diadakan pemeliharaan dan pengawasan sebagai kontrol dengan tujuan solusi yang ditawarkan oleh peneliti mampu berguna dan bermanfaat secara optimal bagi siswa.

\section{KESIMPULAN}

Mengingat Indonesia memiliki tingkat kerawanan tinggi terhadap bencana dan kondisi kesiapsiagaan masih tergolong rendah, maka upaya untuk meningkatkan pengetahuan kebencanaan harus diberikan sejak dini. Sesuai dengan Undangundang Nomor 24 Tahun 2007 tentang Penanggulangan Bencana, anak-anak dikelompokkan dalam kategori rentan. Prioritas pengurangan risiko bencana perlu diimplementasikan ke dalam sektor pendidikan dengan tujuan untuk mewujudkan generasi tangguh bencana. Peningkatan pemahaman mengenai kebencanaan dapat dilakukan melalui kegiatan sosialisasi yang dapat mengedukasi dengan tujuan dapat mengurangi risiko terjadi bencana di suatu wilayah. 


\section{DAFTAR PUSTAKA}

Badan Pusat Statistik [BPS]. (2018). Statistik Daerah Kecamatan Selo 2018: Badan Pusat Statistik Kabupaten Boyolali.

BNPB. (2018). Data Informasi Bencana Indonesia. (Artikel Web). Diakses di http:// dibi.bnpb.go.id/dibi/.

Dariyo, A. (2013). Dasar-dasar Pedagogi Modern. Jakarta: Indeks.

Duval, T.S., \& Bovalino, K. (2000). Tornado Preparedness of Students, Nonstudents Renters, and Nonstudent Owners: Issue of Pre Theory. Journal of Applied Social Psychology, 30 (6), 1310-1329.

Emosda, Lela, \& Fadzlul. (2014). Mengkonstruk Pemahaman Masyarakat Peduli Bencana Alam Banjir. Jurnal Pengabdian Masyarakat, 29 (3), September, 2129.

Herdwiyanti, F., Sudaryono. (2013). Perbedaan Kesiapsiagaan Menghadapi Bencana Ditinjau dari Tingkat Self-Efficacy pada Anak Usia Sekolah Dasar di Daerah Dampak Bencana Gunung Kelud. Jurnal Psikologi Kepribadian dan Sosial, 2 (1), 136-141.

Honesti, L., Nazwar D. (2012). Pendidikan Kebencanaan di Sekolah-sekolah di Indonesia Berdasarkan Beberapa Sudut Pandang Disiplin Ilmu Pengetahuan. Jurnal Momentum, 12 (1), 51-55.

Lesmana, C., Nurul, P. (2015). Kesiapsiagaan Komunitas Sekolah dalam Menghadapi Bencana di Kabupaten Magelang. Jurnal Teknik Sipil, 11 (1), 17.

Peek, L. (2008). Children and Disasters: Understanding Vulnerability, Developing Capacities, and Promoting Resilience - An Introduction. (Artikel Web). Diakses di http:// www.jstor.org/ stable/ 10.7721/ chilyoutenvi.18.1.0001.

Peraturan Pemerintah Nomor 21 tahun 2008 tentang Penyelenggaraan Penanggulangan Bencana.

Rinaldi. (2009). Kesiapan Menghadapi Bencana Pada Masyarakat Indonesia. Jurnal Penelitian Psikologi, 14 (1).

Sugiyono. (2007). Metode Penelitian Bisnis. Alfabeta. Bandung.

Sulistyaningsih, W. (2011). Pemulihan Anak Pasca Bencana: Pelibatan Komunitas untuk Hasil Intervensi yang Efektif. Fakultas Psikologi Universitas Sumatera Utara.

Sunarto, N. (2012). Edukasi Penanggulangan Bencana Lewat Sekolah. (Artikel Web). Diakses di http:// bpbd.banjarkab.go.id/?p=75.

Undang Undang Republik Indonesia Nomor 24 Tahun 2007 tentang Penanggulangan Bencana. (2007). Jakarta: Masyarakat Penanggulangan Bencana Indonesia (MPBI). 